\title{
hISTÓRIA POLÍtICA E CULTURA DO MEDO
}

\author{
Prof. Dr. Antonio Torres Montenegro'
}

Resumo: Este artigo reflete meu percurso de pesquisa histórica nos últimos seis anos, e nele privilegio aspectos que considero relevantes nas produções realizadas que se consubstanciaram em artigos e capítulos de livros. O objetivo ao escolher esse caminho é o de refletir e mapear os deslocamentos teóricos e metodológicos, os aprendizados, considerando as contribuições de diversos autores, os desafios e encruzilhadas, o diálogo com a historiografia num nível geral e também específico. As reflexões metodológicas foram construídas num diálogo com documentos da imprensa, do DOPS, da literatura de cordel além de relatos orais de memória relativos aos acontecimentos políticos das décadas de 1950 e 1960.

Palavras-chave: História Política; História Oral; Repressão Política; Medo; Brasil Século XX

\begin{abstract}
This article reflects my recent journey in historical researching, paying special attention to what I have considered as relevant issues in articles and book chapters written in the last six years. The objective in choosing this path is to reflect and map the theoretical and methodological shifts, the challenges and shifts of my historical learning, considering the contributions of various authors, and the dialogue with historiography in general and specific level. Methodological reflections were constructed in a dialogue with sources as newspapers, documents of DOPS, the "chap-books" in addition to oral reports of memory for the political events of the 1950s and 1960s.
\end{abstract}

Key Words: Political History; Oral History; Political Repression; Fear; Brasil XX Century

\section{LUTAS POLÍTICAS NO CAMPO.}

Inicio pela análise de um projeto de pesquisa histórica que teve como título Memórias da terra: a Igreja Católica, as Ligas Camponesas e as esquerdas (1954-1970), o qual resultou em diferentes caminhos suscitados pela pesquisa

I Professor do Departamento de História da UFPE. Email para contato: antoniomontenegr@hotmail.com 
documental, associada ao debate historiográfico. A problemática metodológica que se apresentou constantemente em razão do cruzamento 'documentação \& historiografia’ contribuiu de maneira decisiva para a análise de um período histórico no Brasil marcado por um avanço dos movimentos sociais rurais e urbanos, até o golpe civil-militar que se instalou em 1964 e a repressão aos movimentos sociais que então se seguiu.

No texto publicado como capítulo de um livro da coleção Brasil Republicano, com o título Ligas Camponesas e sindicatos rurais em tempo de revolução² ${ }^{2}$ desenvolvi uma ampla reflexão sobre a organização das Ligas Camponesas no estado de Pernambuco e sua atuação no Nordeste do Brasil, entre o final da década de 1950 e início da década de 1960. Para este estudo pesquisei com a documentação do $\mathbf{D O P S}^{3}$ - hoje depositada no Arquivo Público Estadual de Pernambuco. As Ligas Camponesas se constituíram numa Associação Civil Rural de grande força política, pois surgiram como alternativa aos sindicatos rurais que os grandes proprietários impediam de serem criados.

Nas décadas de 1950 e 1960, a polícia apreendeu farta literatura produzida por algumas lideranças dos movimentos sociais rurais consideradas como integrantes das Ligas Camponesas. Essa documentação possibilitou estudar diferentes aspectos dos discursos e das práticas dos trabalhadores. A imprensa e os relatos orais de memória de trabalhadores e lideranças sindicais e religiosas também se constituíram uma base documental importante para a análise do cotidiano dos embates políticos no campo.

Duas perspectivas de análise fundam a escrita do texto Ligas Camponesas e sindicatos rurais em tempo de revolução. Por um lado, o estudo da acirrada disputa que se estabeleceu entre a Igreja Católica, setores da esquerda (fundamentalmente o Partido Comunista) e as Ligas Camponesas, pela hegemonia na condução das lutas sociais que começavam a eclodir no meio rural em Pernambuco. Nesse aspecto, além de estabelecer as linhas dessa disputa, procuro analisar como a Igreja Católica teve um papel decisivo na criação dos sindicatos rurais pelo Ministério do Trabalho, antes do golpe civil-militar. A formação dos sindicatos rurais foi um meio de enfraquecer as Ligas Camponesas, as quais eram associações civis criadas no vazio deixado pela legislação, que dificultava a fundação dos sindicatos no campo. A disputa de poder entre essas três forças políticas nesse período foi um dos focos centrais das minhas análises.

O segundo aspecto a ser destacado na realização desse estudo foi a opção de pensar o documento (no caso da imprensa) como uma forma de construir o real e, desse modo, estudá-lo como lócus privilegiado, observando como aí se estabelece um acirrado combate entre os diversos grupos sociais no sentido de narrar, da forma mais convincente e, portanto, verdadeira, a história cotidiana. 
Nesse sentido, foi muito revelador analisar a série de reportagens escritas pelo jornalista Antonio Callado sobre as Ligas Camponesas e a situação política de Pernambuco em $1959^{4}$ e, posteriormente, outro conjunto de matérias sobre o mesmo tema, elaboradas pelo jornalista Tad Szulc para o jornal The New York Times em 1960. São os dois mesmos Nordestes completamente distintos a desafiar os deslocamentos analíticos da escrita historiográfica.

Ainda ressaltaria nesse artigo o relato de memória de um trabalhador rural da zona canavieira de Pernambuco, João Lopes da Silva (conhecido por Bubu), que possibilitou refletir sobre as práticas paternalistas e sua ruptura. Em outros termos, como os próprios códigos internos da relação paternalista de compadrio, que permeia as redes de dominação, podem ser motivo de ruptura desse pacto visível/invisível.

Bubu é filho de trabalhador rural. Seu pai plantava cana para o senhor de engenho e tinha direito a um sítio, em que cultivava sua lavoura de subsistência milho, feijão, macaxeira -, e podia algumas vezes levar um excedente para vender na feira no final de semana. Mas essa prática seria alterada ao surgir a proibição do direito de sítio para os trabalhadores da cana. Nas lembranças de Bubu, esse momento é reconstruído através de diversas experiências que se intercalam em um tempo simultâneo:

[...] foi quando eu me casei; bom, adepois, quando adepois de muito tempo, o senhor de engenho, todo senhor de engenho combinava. Que tem lá a Federação dele, a sede e dizia: não vai mais dar sítio a filho de lavrador. A gente agora só quer eles tudo para trabalhar no eito da cana. Quando a gente ia pedir sítio... eles dizia não, dá não, tudo pro eito. ${ }^{5}$

Este pequeno fragmento de seu relato de memória revela a forma como para o narrador foi entendida a medida de proibir os sítios em que os trabalhadores da monocultura da cana plantavam sua agricultura de subsistência. Poder-seia pensar que com a proibição do direito ao sítio os próprios senhores contribuíram para a ruptura de um dos elos que constituíram e cimentaram a secular relação paternalista entre senhores e trabalhadores. No entanto, para Bubu, outro acontecimento iria concorrer, de forma mais radical ainda, para romper seus laços com as práticas paternalistas que o prendiam ao engenho Mamulenga. Recorda, então, uma doença que a mulher contraiu, ocasião em que decidiu pedir ajuda ao patrão:

[...] quando a mulher adoeceu aí fui lá; disse: “Seu Júlio, eu quero que o senhor me empreste dez mil réis, para comprar um vidro de remédio para a mulher.” Seu Júlio respondeu: “...é, João Lopes, eu vou...” Eu ganhava naquele tempo, dois mil 
réis e quinhentos réis, naquela época. Ele disse: “...é, eu vou aumentar para três mil réis, não posso emprestar dinheiro, não!” Eu digo: tá certo... Vim para casa. Papai disse: “João, vá lá em casa buscar o dinheiro”, aí eu fui, papai me emprestou dez mil réis, fui em Aldeia de São Sebastião, comprei um vidro de água inglesa para a mulher, ela tomou e ficou boa. ${ }^{6}$

Esse acontecimento teve um significado radical para Bubu. O pacto paternalista, para ele, foi rompido de forma definitiva com aquela recusa do senhor em ajudar à sua mulher que adoecera. Sobretudo, porque já vinha pensando em trabalhar em outros lugares ou mesmo mudar-se para a cidade de Recife. Porém, antes de entregar a enxada e a casa ao patrão, queria mostrar que um trabalhador como ele merecia outro tratamento. E não esquece de narrar a promessa que fez a si próprio naquela oportunidade:

Eu vou mostrar a Seu Júlio o que é um trabalhador... quando chegava no serviço, metia a enxada para cima. A gente estava no mês de São João cavando rego de cana. Eu metia na frente, puxava o eito assim, eu gritava: "Puxa a beira e o canto, deixa o meio pra dia santo, corre o canto e a beira, deixa o meio para segunda-feira”, pá, pá, pá... os outros homens limpando, quase cem homens, para cavar rego... pá, pá, pei, pei, pei... quando foi no mês de agosto, encontrei compadre Roseno no rancho, e ele disse: "Compadre, sua vaga na usina está arrumada. Você vai segunda-feira falar.” ... eu fui, cheguei lá arrumei a vaga... Voltei para Mamulenga, trabalhei mais quatro dias, quando foi na sexta-feira, nesse dia trabalhei que só não sei o quê. Quando cheguei no serviço, disse: "Olhe! Só sou morador de Mamulenga até hoje! De hoje em diante, não sou mais.” Aí o pessoal dizia: "Tu bebesse água do açude de Mamulenga, tu não sai mais nunca.” Eu digo: “Tá certo.” Vou, aí comecei, eu vou me embora, peitei, quando larguei de cinco horas, peguei a enxada, cheguei assim, digo: "Pronto, seu Júlio, está aqui sua enxada, só sou morador do senhor até hoje, de hoje em diante não sou mais.” Aí ficou: "O que é isso seu João?” Digo: “...é sim senhor, seu Júlio, porque eu quero patrão para quando eu precisar da minha necessidade precisar dele, mas de um patrão, quando chega minha necessidade, ele não me serve, para mim não dá."’

João Lopes rompeu com o espaço opressor, mas antes trabalhou até os limites de suas forças, como para provar a si mesmo que seu valor estava além do reconhecido pelo senhor. Era um trabalhador exemplar, que provavelmente ninguém imaginava que estivesse preparando o golpe, o lance. Afinal, era o próprio líder dos cem homens que cavavam o rego para plantar a cana, puxando na 
voz o ritmo da enxada. Mas, antes, garantiu outro emprego na usina de açúcar. E sua tenacidade se define também pelo prazer em romper com as regras que regiam a relação patrão/empregado, as quais, na sua representação, não lhe atribuíam o valor de que se considerava merecedor. Por outro lado, ao anunciar aos companheiros que estava de partida, estes lhe relembraram o efeito mágico das águas do açude, que tornava todos prisioneiros de seu próprio destino: o de viver e morrer trabalhando naquele engenho. João, entretanto, não se intimidou, enfrentando os companheiros e sua água servil, e o patrão, que não acreditava no que ouvia daquele trabalhador dedicado. Com a consciência de que quem rompera o contrato fora o senhor, declinou as razões de sua decisão de pedir demissão ao dizer: "patrão, quando chega minha necessidade, ele não me serve, para mim não dá.”

Teria João realmente dito ao patrão que ele não atendera sua necessidade e por isso estava indo embora?! Ou aquela era uma representação silenciosa que elaborara, mas que sempre guardara para si próprio, revelando-a apenas ao reconstruir sua memória oral?! No entanto, essa resposta nunca será obtida. Apenas sabemos que ela apresentou-se naquele momento de recordação, reconstrução dos tempos de despedida como trabalhador rural do engenho Mamulenga.

O fragmento de memória da história de vida de João Lopes possibilita compreender como algumas relações de dominação no meio rural do Nordeste, nos meados do século XX, vinham se transformando: o senhor não mais cedia o sítio para o trabalhador produzir uma lavoura de subsistência; colocava-se a possibilidade de mudança para o Recife ou para outros locais de trabalho, em face da ruptura do pacto patriarcal, pois os senhores pareciam atender cada vez menos à antiga representação de que supriam a necessidade do trabalhador.

\section{O MEDO COMO QUESTÃO POLÍTICA}

Em 2004, publiquei o artigo Labirinto do medo: o comunismo (19501964) ${ }^{8}$, no qual parti do estudo dos incêndios nos canaviais de açúcar no estado de Pernambuco no final da década de 1950 e início da década de 1960. Duas linhas básicas de análise definiram a construção desse artigo. Por um lado, a discussão sobre a forma como, a um acontecimento comum no período - o incêndio de canaviais -, na denominada zona da Mata de Pernambuco, foi associada uma outra rede de significação, ou seja, a ameaça comunista. Na imprensa, no rádio, nas feiras livres do interior, nos púlpitos das igrejas, era reafirmado que os incendiários dos canaviais não passavam de comunistas que desejavam destruir a propriedade, a religião e a família. Assim, era produzida toda uma representação de medo, de temor associado aos incêndios dos canaviais. Na época não era uma prática comum a queima antes do corte da cana, como se faz hoje. 
Paralelamente, pesquisando nos arquivos, encontrei uma reportagem na imprensa do período que me chamou muito a atenção. Em letras garrafais, encabeçava a página policial do jornal Diário de Pernambuco uma chamada que anunciava: "Avião ateou fogo no canavial do engenho 'Cairá': testemunha narra fato ao Diário”. ${ }^{9}$ Logo abaixo, a fotografia de um canavial incendiado e, ao lado, a imagem de uma criança em trajes próprios de trabalhador rural, aparentando uns dez anos. A legenda da foto informava que a criança havia visto o avião jogar algo e logo em seguida o fogo se espalhara no meio da cana. A matéria dizia, inicialmente, que alguns senhores da região falaram à reportagem que, provavelmente, aquele incêndio era de responsabilidade do líder das Ligas Camponesas, Francisco Julião. Este teria afirmado que tinha condições de incendiar todos os canaviais de Pernambuco, caso os patrões não cumprissem com suas obrigações trabalhistas. No restante da matéria, eram transcritos relatos de trabalhadores, moradores da região, donos de barracões, nos quais alguns até afirmavam que não acreditavam que um avião houvesse lançado fogo no canavial.

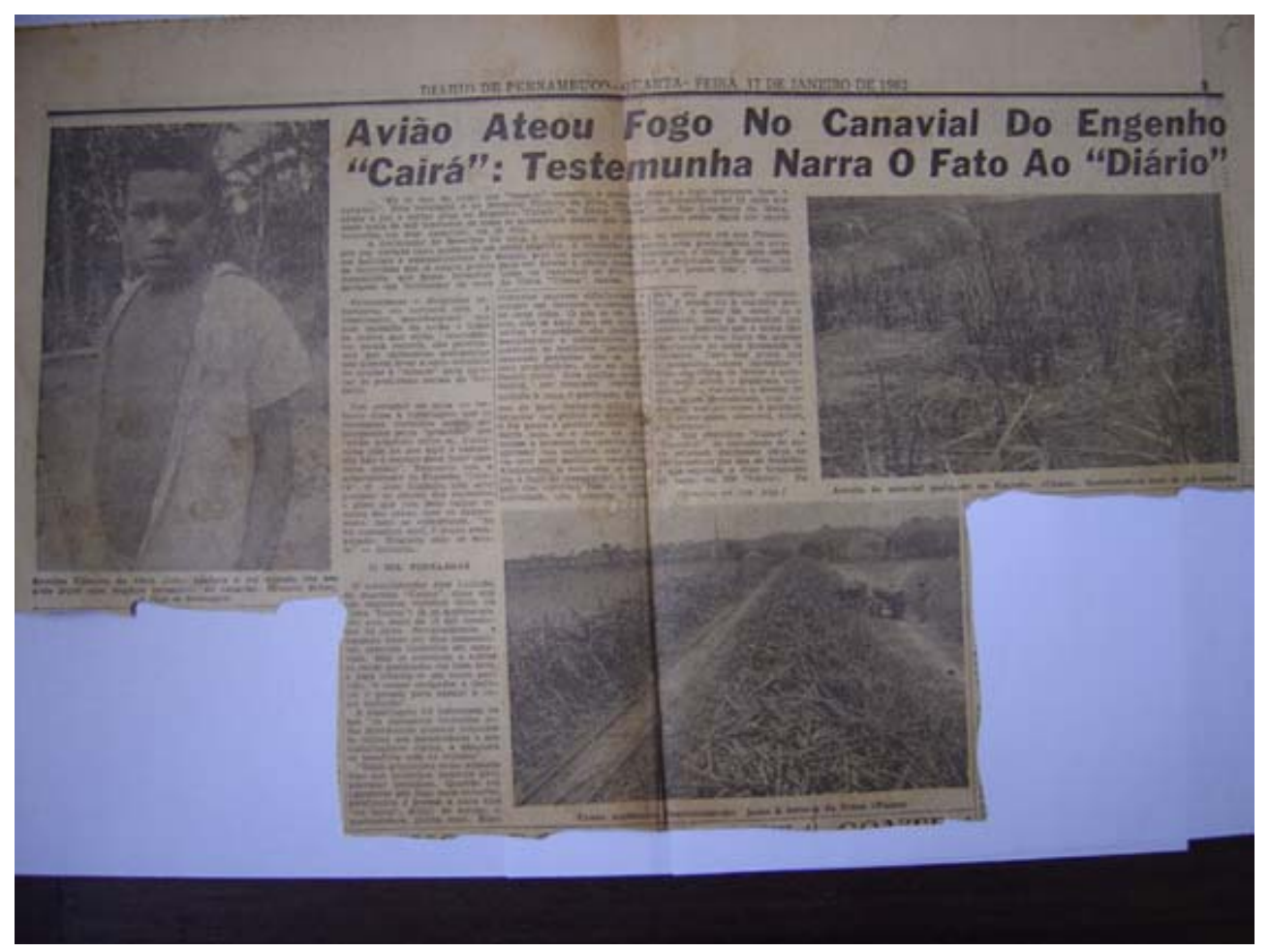


A grande surpresa para mim na pesquisa com essa documentação foi encontrar um relatório de 14 páginas, produzido por dois agentes da polícia de Pernambuco, acerca desse episódio. Esses agentes policiais foram encarregados de fazer uma investigação no local do incêndio. Durante vários dias, percorreram diversos engenhos da região, conversando com trabalhadores, senhores de engenho, administradores, vigias e donos de barracão. O resultado de toda essa peregrinação é um rico documento, onde a história do avião incendiário é inteiramente desconstruída, pois os trabalhadores afirmam de forma unânime que "aquilo é história de menino, ninguém ali acredita”, e vem à tona uma ampla série de fatores que contribuía para a ocorrência daqueles incêndios. Para minha surpresa, os agentes narram no relatório que as razões dos incêndios nos canaviais, segundo as pessoas com as quais conversaram nos engenhos, eram: pontas de cigarro jogadas nas margens da estrada; os caçadores de passarinhos com suas espingardas soca-soca, que carregavam pela boca do cano e o tiro expelia uma bucha de palha seca que provocava incêndios; ou mesmo a própria imprevidência de donas de casa que, ao varrerem os restos das cinzas dos fogões de lenha, jogavam os mesmos próximo aos canaviais. Não há no relatório confidencial escrito por esses agentes nenhuma referência a comunista ou 'pessoal das Ligas Camponesas', como costumava aparecer na imprensa. Pelo contrário, o que surge no relatório são os incêndios associados também a uma estratégia de sobrevivência, pois, algumas vezes, o trabalhador, por se encontrar sem o dinheiro da feira do final de semana, ateava fogo aos canaviais com o objetivo de obrigar o proprietário a imediatamente realizar o corte da cana, uma vez que a cana queimada precisa ser cortada no prazo de 48 horas, senão perde a sacarose e não serve para produzir açúcar.

Em resumo, a documentação que fui descobrindo em razão da pesquisa me conduziu para uma realidade inteiramente distinta daquela que a imprensa no período anunciava. E o mais surpreendente foi realizar esse percurso tendo como documento um relatório policial confidencial enviado ao delegado auxiliar do estado de Pernambuco no período que nunca veio a público.

Outro momento significativo da pesquisa foi o ano de 2004 - portanto, quarenta anos após o golpe civil-militar de 1964 no Brasil -, quando foram promovidos diversos seminários de norte a sul do país para discutir e analisar os múltiplos significados, as diferentes produções historiográficas, as diversas memórias acerca desse trágico acontecimento. Escrevi um artigo, As Ligas Camponesas às vésperas do golpe de $1964^{10}$, que inicio tomando como referência uma reflexão de Gramsci, na qual ele afirma que, em sentido espontâneo, todas as pessoas são filósofas. Talvez seja possível dizer o mesmo em relação ao historiador, ou seja, em sentido espontâneo, todas as pessoas são historiadores e historiadoras, pois estão constantemente 
narrando histórias e, sobretudo, retornando à memória do passado e repensando-o, ressignificando-o. A partir desse movimento de análise do passado, muitas vezes ocorre das pessoas redefinirem sua forma de compreender e agir no presente e de refletir acerca dos projetos futuros.

Em seguida, procuro mostrar como o historiador tem uma maneira sistemática de repensar o passado. Em outros termos, o exame da historiografia, a possibilidade de acesso a novos documentos, novas abordagens metodológicas associadas às experiências do presente produzem novas perguntas e a reescrita da história. Dessa maneira é que procuro pensar a história do golpe civil-militar de 1964 da perspectiva dos movimentos sociais rurais do Nordeste, em especial as Ligas Camponesas. Associada a essa preocupação teórica, recupero uma documentação do DOPS em que os agentes policiais, ao escreverem ao Delegado Geral seus relatórios acerca das greves em alguns engenhos, ao tempo em que informam quem são os líderes do movimento, afirmam também que os proprietários cometem muitas injustiças contra os trabalhadores. Assim, é possível perceber indícios de uma mudança de atitude da própria polícia, que começava a apontar como não sendo mais aceitáveis as relações de trabalho impostas por determinados proprietários. Dessa forma, o artigo, ao mesmo tempo em que analisa o refazer crítico da historiografia, recuperando o debate sobre o golpe de 1964, mostra como uma parcela da polícia em Pernambuco se colocou em face das constantes greves de trabalhadores no meio rural. O discurso da polícia, em parte, rompe com a afirmação de que toda mobilização dos trabalhadores resultava da ação dos comunistas e das Ligas Camponesas, como a imprensa costumava noticiar. No entanto, o discurso dominante na documentação pesquisada é de que a sociedade assistia a um crescente descontrole e anarquia, sobretudo porque o aparelho de Estado no nível municipal e estadual estava dominado por políticos de esquerda.

\section{HISTÓRIA E MEMÓRIA: TRILHAS METODOLÓGICAS}

Outro texto publicado foi Arquiteto da Memória: nas trilhas dos sertões de Crateús ${ }^{11}$, elaborado no bojo da pesquisa Memórias da terra: a Igreja Católica, as Ligas Camponesas e as esquerdas (1954-1970). O ponto de partida para este texto foi uma longa entrevista com dom Antonio Fragoso, exbispo da cidade de Crateús, no estado do Ceará, realizada entre outubro e dezembro de 2003. Essa entrevista de história de vida, de mais de 12 horas, exigiu diversas viagens da cidade de Recife, onde vivo, à cidade de João Pessoa, capital do estado da Paraíba, onde Antônio Fragoso passou a morar depois de sua aposentadoria como bispo de Crateús. Seu próprio relato de sua história de vida instituiu um outro dom Fragoso, distinto daquele que aparece na historiografia da 
Igreja Católica no Brasil, ou mesmo em relatos de memórias de padres que tiveram oportunidade de com ele atuar. O religioso de posições políticas firmes, inquebrantáveis, sempre pensando na lógica de um cristianismo a favor dos trabalhadores mais pobres, revelou-se também um homem de fala pausada e afetuosa, apreciador das rosas e sempre muito atento e curioso em saber mais sobre minhas pesquisas no campo da história.

Esse texto, que focaliza a atuação de dom Fragoso e sua pastoral rural fundada na Teologia da Libertação, se inicia com o relato de memória de um padre francês que, por volta de 1963, chegou à cidade de São Luís, capital do estado do Maranhão. O padre Xavier Gilles de Maupeou viera de Paris para trabalhar na diocese de São Luís, onde dom Fragoso era bispo auxiliar, antes de ser transferido para a cidade de Crateús. Em seu relato de memória, numa entrevista que realizei para outro projeto de pesquisa, denominado Guerreiros do alémmar, ele narra o choque que foi a primeira conversa com dom Fragoso, no palácio episcopal em São Luís. Embora dom Fragoso, quando indagado sobre o episódio, nada lembrasse, essa recepção nunca fora esquecida por Xavier, que a narrou ainda cheio de emoção:

"Xavier, nós pedimos um padre para o mundo operário. Tínhamos necessidade de um padre que viesse do mundo operário. Tu não vens do mundo operário, tu não conheces o mundo operário. Precisávamos de um padre maranhense, mas não temos, e tu não sabes nada do Maranhão.” Em seguida apresentou-me a uma moça, que estava ao nosso lado e disse: "Estás vendo essa moça, ela faz parte de uma pequena equipe de jovens trabalhadoras. Elas vão te ensinar tua tarefa sacerdotal, tua profissão de padre.” Foi através dessa equipe composta de oito moças que comecei a entrar no mundo operário dos bairros de São Luís. ${ }^{12}$

A mim, pessoalmente, sempre me encantam os fragmentos de memória construídos a partir de pequenos relatos de casos, que se transformam em verdadeiras histórias. Não apenas pelo caráter inusitado e surpreendente que na maioria das vezes estas apresentam, mas sobretudo pelo que trazem de marcas, de sinais, de índices que desafiam a leitura historiográfica. E você, caro leitor, deve então se perguntar que sinais teria eu lido nessa curta reconstrução de memória de um encontro entre dois religiosos. Um religioso nordestino, mesmo ocupando uma posição superior - bispo auxiliar -, recebia um religioso estrangeiro e afirmava que toda a sua formação eclesiástica nos seminários da França de nada valia para atuar no Brasil. Seria então necessário um novo período de aprendizagem, onde os professores seriam não os doutores da terra, mas uma equipe de jovens trabalhadoras. 
A proposta apresentada ao padre Xavier apontava para uma nova relação de poder e saber. Um padre francês iria reaprender seu ofício com trabalhadoras da cidade de São Luís, ou seja, a formação intelectual e todo um conjunto de experiências trazidas da Europa pouco ou nada valiam. Talvez por isso padre Xavier nunca tenha esquecido esse acontecimento, pois significava um choque, uma anulação da sua percepção e compreensão da ordem das coisas. Em outros termos, uma inversão do discurso iluminista e da prática colonialista que se instalara quase que de forma natural nas relações culturais, comerciais e políticas entre a Europa, os EUA - os denominados países do Norte - e as nações deste outro lado do continente. Porém, o choque teve ainda outra dimensão cultural, provavelmente inimaginável para o padre recém-chegado: suas professoras seriam mulheres, e não homens. Ou seja, um padre iria aprender seu oficio exatamente com aquele tipo de pessoa que os seminários instituíram como uma grande ameaça, simbolizada em Eva e na eterna tentação do pecado e a expulsão do Paraíso. É importante relembrar que esse encontro entre Xavier e dom Fragoso ocorreu no início da década de 1960, quando a luta pela igualdade de direitos das mulheres ainda dava seus primeiros passos e a Igreja não tinha concluído o Concilio Vaticano II, que aprovou algumas práticas modernizadoras. Há de se considerar, ainda, que não era fortuito que o padre Xavier, ao narrar sua história de vida por meio de um relato oral de memória, recriasse o diálogo que se estabelecera no seu primeiro encontro com o bispo auxiliar de São Luís e, mesmo passados mais de trinta anos, ainda reavaliasse esse encontro como um momento difícil.

Um ano após esse memorável encontro entre o padre Xavier e o bispo auxiliar, ocorreu o golpe de 1964. Dom Fragoso, que estava então cotado para ser nomeado arcebispo de São Luís do Maranhão, foi denunciado como comunista ao $4^{\circ}$ Exército e enviado para ser o primeiro bispo da recém-criada diocese de Crateús, situada no sertão do estado do Ceará, a 300 km da capital Fortaleza. Para alguns era a mesma coisa de ser mandado para atuar como bispo na Sibéria brasileira. No entanto, mesmo na distante cidade de Crateús, Fragoso transformaria sua diocese numa referência nacional e internacional de uma igreja militante pela causa dos trabalhadores. Após mais de trinta anos de bispado dedicado a Crateús, Fragoso se aposentou e se despediu para nunca mais retornar a essa cidade. Ouvi-lo foi de certa maneira conhecer a história de muitas crianças pobres do interior do Nordeste do Brasil, que cedo ingressam nos seminários menores e, muitas vezes, não têm o dinheiro da passagem do ônibus para ir visitar os pais no interior dos seus estados.

Nesse texto, o fio condutor não se reduz à narração da história invulgar desse combativo bispo, que na década de 1970 era nomeado de progressista, mas abrange a análise de seu grande esforço para transformar em documento, e também em história, sua intensa e longa experiência sacerdotal em Crateús. Um 
guerreiro invulgar na sua cruzada por converter em história escrita sua ação pastoral naquela distante cidade. ${ }^{13}$

Em razão do intenso trabalho com as fontes documentais orais e escritas, e também devido ao fato de ministrar na Pós-Graduação em História da UFPE a disciplina Metodologia da História, produzi alguns trabalhos de caráter mais teórico-metodológico.

Esse itinerário de pesquisa, aliado à docência de uma disciplina de caráter teórico, concorreu para a escrita do texto Rachar as palavras: uma história a contrapelo. ${ }^{14}$ Este trabalho significou um esforço de síntese metodológica de um processo de investigação e reflexão que fui construindo desde 2003. Diferentemente de outros artigos de caráter metodológico já escritos por mim, neste busco associar a problemática teórica ao trabalho de análise histórica de alguns documentos orais e escritos. Para efetivar esse percurso, procuro mostrar como os debates atuais da física e da matemática encontram-se muito próximos da discussão historiográfica apontada por Paul Veyne e Michel Foucault. Ou seja, a partir da física moderna não existem mais coisas com qualidades intrínsecas; elas dependem do meio ambiente. No nível subatômico, os objetos materiais sólidos da física clássica dissolvem-se em padrões ondulatórios de probabilidades. E estas não são probabilidades de coisas, ou de objetos, mas de interconexões. Assim, na teoria quântica os físicos não lidam com 'coisas', mas com relações. Ou ainda, como escreveu o físico Niels Bohr, "as partículas materiais isoladas são abstrações, e suas propriedades são definíveis e observáveis somente através de sua interação com outros sistemas” ${ }^{15}$. Dessa forma, o foco da análise da física não seria mais o objeto, mas as relações, porque isoladamente a natureza, no nível subatômico, não revelaria qualquer objeto. ${ }^{16}$ Assim, se não temos objetos, nem um mundo a ser descoberto, mas relações ou interconexões, as palavras também, ao serem enunciadas, não oferecem por si a verdade do mundo. Por extensão, não é possível mais estabelecer definições em que as palavras ou os conceitos conteriam o próprio sentido e significado do mundo. As palavras, desse modo, não operam como representação mágica que ao ser enunciada revelaria o conhecimento, de forma clara e objetiva.

Poder-se-ia encontrar, nessa representação do mundo que a física moderna cria, um estreito paralelo com a história, na perspectiva da análise desenvolvida por Paul Veyne, quando afirma:

Dito de outra maneira, é preciso desviar os olhos dos objetos naturais para perceber uma certa prática, muito bem datada, que os objetivou sob um aspecto datado com ela; pois é por isso que existe o que chamei anteriormente, usando uma expressão popular, "parte oculta do iceberg": porque esquecemos a prática para não mais ver senão os objetos que a reifi- 
cam a nossos olhos... Em vez de acreditar que existe uma coisa chamada "os governados" relativamente à qual os governados se comportam, consideremos que os governados podem ser tratados seguindo práticas tão diferentes, de acordo com as épocas, que os ditos governados não têm senão um nome em comum. ${ }^{17}$

Em outras palavras, Veyne está colocando que também na história as coisas, os objetos, os seres, isoladamente, nada expressam, além do seu significante. No que tange ao termo governado, por exemplo, este só existe ou só adquire significado histórico mediante o estudo de suas práticas, analisando suas relações. E seria essa uma das grandes contribuições de Foucault para a história, na visão de Veyne.

Foucault observa que "o problema é ao mesmo tempo distinguir os acontecimentos, diferenciar as redes e os níveis a que pertencem e reconstituir os fios que os ligam e que fazem com que se engendrem, uns a partir dos outros." ${ }^{18} \mathrm{~A}$ partir do estudo das relações, das práticas, dos fios, das ligações, que são associados a acontecimentos, é que podemos construir formas de entendimento histórico. Ou ainda, como afirma Deleuze, a questão não é mais estudar a origem ou a causa, nem a finalidade ou a conseqüência, mas o que se passa entre ${ }^{19}$. Dessa maneira, a análise histórica tem como foco primordial as relações, os percursos, as práticas, porque através do seu estudo é que se poderão construir outras formas de compreensão, que desnaturalizem a relação ou a representação que procurava associar de forma unívoca o objeto ou a coisa à palavra. É nessa perspectiva que Deleuze e Veyne irão reafirmar a proposta de Foucault de "rachar as palavras”, rachar as coisas. Desnaturalizá-las e ir em busca dos fios que as engendram, que as significam.

Rachar as palavras, romper seus liames naturalizados e evidentes com as coisas, com o que se denomina real. A história como o digladiar de sentidos, produzidos pelos jogos da linguagem ${ }^{20}$, nos remete a Certeau, quando afirma: "Parece que não se podendo mais atribuir às palavras uma relação efetiva com as coisas que designam, elas se tornam tanto mais aptas para formular sentidos, quanto menos limitadas são por uma adesão real.”21

Nesse território, torna-se fecundo privilegiar a postura teórica de Wittgesnstein, ao considerar em suas reflexões filosóficas o discurso comum das pessoas, e não o dos filósofos. E é através dele que revisito o trecho da entrevista do líder comunitário Arnaldo Rodrigues da Cruz.

Na década de 1970, em pleno regime militar no Brasil, teve início uma mobilização em defesa da moradia, num grande bairro popular de Recife, denominado Casa Amarela. Desde a década anterior, os agentes imobiliários vinham tentando expulsar os moradores por meio da cobrança do foro da terra. Esta 
tentativa recrudesceu, já que a imobiliária, em princípio, contava com o apoio oficial para reprimir qualquer manifestação popular de protesto contra essa cobrança, considerada indevida e irregular pela população. A censura reinante no período, aliada ao medo que muitos cidadãos passaram a sentir de vir a ser nomeados de comunistas ${ }^{22}$ por participar de qualquer movimento social, era um fator que concorria bastante para a desmobilização popular. No entanto, mesmo diante desse conjunto de adversidades, um grupo de moradores iniciou uma organização denominada Terra de Ninguém e, com o apoio da Igreja Católica e de outros setores, conseguiu, após anos de luta, a desapropriação das terras e o título de propriedade para seus moradores. ${ }^{23}$

Esse preâmbulo tem como objetivo apresentar o relato de um dos moradores que participou ativamente de todo o trabalho de organização e mobilização contra a imobiliária e seu dono, Rosa Borges. Ao relembrar o que se denominou luta das Terras de Ninguém, Arnaldo afirma:

Eles [a imobiliária] nunca foram dono de nada e hoje ele se diz dono de tudo e todo mundo acredita que ele é dono. Mas que eles nunca foram donos de nada, mas de nada mesmo, isso é preciso vocês [os moradores] botarem na cabeça de vocês, tirar da cabeça de vocês, porque tirando da cabeça de vocês, vocês levam para outro conscientes, mas enquanto estiver na cabeça de vocês, vocês não leva não. Vocês vão dizer: não, mas... fica gaguejando. ${ }^{24}$

Este pequeno fragmento do relato já revela uma perplexidade, entre a palavra (dono) e a coisa (as terras de Casa Amarela). Como seria possível construir uma ligação entre a palavra dono e a coisa, terras de Casa Amarela, se esta para Arnaldo não existe? A resposta, segundo ele, estaria no fato das pessoas acreditarem. E lembra que, enquanto os moradores não retirarem de suas próprias cabeças a proposição ele é dono, a luta estará enfraquecida, porque eles não terão firmeza, ficarão gaguejando. Ou seja, para Arnaldo não existe a divisão cartesiana entre matéria e espírito, corpo e alma. A prática das lutas sociais lhe ensinou que o pensamento e a ação são indissociáveis, estão misturados. A ação e o pensamento constituem um mesmo conjunto. E em seguida amplia sua reflexão, ao indagar: "E como ele se diz proprietário? Aí é que é danado. Aí é que está a história. É o furto, a roubalheira, a ladroíce, que existe dentro da política, junto com juiz, advogado, não sei quantos diabos, que fizeram isso. Fizeram Rosa Borges ser dono daquilo que não era dele.”25

Para responder a sua própria pergunta, Arnaldo retorna à história e detalha os procedimentos, os fios, os caminhos trilhados, pois proprietário não é uma palavra que se associa a uma coisa, a um objeto de maneira natural. Mas o 
proprietário que se diz Rosa Borges resultou de operações complexas. Ao detalhar esses movimentos que associam, estabelecem elos, colam significados, Arnaldo está quebrando, rachando, desnaturalizando aquela palavra, aquela história. E acrescenta:

A história ele conta assim. Bom, ele fez tudo isso. E a lei, a
própria lei. É danado, é isso. É eu dá uma tapa em você, sem
você abusar comigo, mas eu tenho dinheiro e chego lá na
delegacia prendo você, você fica preso e eu venho embora.
Foi isso o que Rosa Borges fez, veio para Casa Amarela, tomar
conta de tudo, dominou tudo, hoje em dia se diz dono de Casa
Amarela, propriedade imensa e ele diz que é dele, mas Santos
Marinho foi que deu a mão a ele. Foi que botou ele aqui e ele
ficou aqui dentro, depois ele passou a ser administrador, ele é
que diz. Passou a ser administrador na história. E, através da
administração, como não tinha dono, ele passou a ser dono.
Ele que diz. ${ }^{26}$

Ler o relato de Arnaldo é aprender com ele, um ex-operário têxtil, que ao descrever a experiência de luta em defesa da sua moradia oferece um breve tratado acerca do combate que se trava na história. Como a história é o que se diz, é resultante de muitos procedimentos de força que delimitam, cercam, cortam, estabelecem elos, subvertem significados, rompem acordos. E consciente do perigo da história, Arnaldo torna-se professor, e didaticamente explica como os signos são trocados, os significados mudados de lugar pela força do dinheiro. E como quem se sabe um educador, narra uma breve história: “É eu dá uma tapa em você, sem você abusar comigo, mas eu tenho dinheiro e chego lá na delegacia prendo você, você fica preso e eu venho embora.” Para Arnaldo a história da propriedade da terra em Casa Amarela é plural, resultando num combate entre um dizer do Rosa Borges e outro do movimento dos moradores. E a vitória destes últimos depende entre outros elementos da capacidade de mudar o pensar/agir. A história como desafio e movimento constantes de quem sabe o quanto rachar as palavras exige sabedoria, táticas, trampolinagens de um viver a contrapelo.

Toda essa pesquisa acerca do período que antecede ao golpe civil-militar de 1964 e do período posterior - em que uma violenta repressão se abateu sobre as lideranças dos movimentos populares, as lideranças dos sindicatos combativos e as lideranças dos partidos e organizações de esquerda - levou-me de volta à reflexão sobre a memória histórica. Mais propriamente ao estudo da construção de uma certa tradição de memória que, focalizada em minhas pesquisas, trata da produção, tanto na historiografia como nos meios populares, de uma representação política de que o estado de Pernambuco é um lócus marcado pela resistência e combatividade de seu povo. 
Nesse sentido é que me voltei para a investigação de uma frente eleitoral de esquerda que se constituiu inicialmente em Recife, capital de Pernambuco, a partir de 1955 e que se desmobilizou diante do golpe de 1964. No texto A Frente do Recife chega ao poder (1955-1964) ${ }^{27}$, trabalhei com diversas leituras e interpretações historiográficas que se condensavam basicamente em duas perspectivas de análise: ou reforçavam a tradição combativa de esquerda da população de Recife e de Pernambuco, ou a negavam.

Em síntese, este artigo procurou romper com essas duas visões até então dominantes. Afinal, em diversas eleições os candidatos de partidos considerados de esquerda venceram, no entanto, essas vitórias não autorizam afirmar que tenha existido uma tendência ou uma natureza de esquerda na população, pois também em outros momentos foram eleitos candidatos considerados de direita. A questão fundamental é que essas leituras cristalizam a história, transformando-a em memória histórica ou produzindo identidades que traem o movimento de ressignificação e crítica permanente.

Em outro estudo, publicado em 2007, As Ligas Camponesas e os conflitos no campo ${ }^{28}$, trabalhei basicamente com as representações culturais produzidas pela literatura de cordel sobre temas como: religião, trabalho, liberdade, latifúndio. Esta literatura era recitada por cantadores com suas violas nas feiras populares das pequenas cidades do Nordeste do Brasil. As Ligas Camponesas se apropriaram desse importante veículo de reprodução da cultura popular, até então profundamente marcada por valores tradicionais como honra, tradição, respeito à família, respeito a Deus e respeito à ordem constituída, e introduziram um novo discurso. Os cordéis passaram a ser uma arma poderosa de crítica aos ricos, ao latifúndio e, sobretudo, a uma certa Igreja que apoiava a manutenção do status quo dominante:

O latifúndio diz assim: "Deus castiga aquele que se rebela contra ele. Se um é rico e outro é pobre, se um tem terra e outro não, se um deve trabalhar com a enxada para dar o 'cambão' e outro se mantém e se enriquece com o fruto desse 'cambão', se um vive num palácio e o outro numa palhoça, é porque Deus quer. Quem se rebela contra isso, se rebela contra Deus. Sofre os castigos do céu: peste, guerra e fome. E quando morre vai para o inferno. O pobre deve ser pobre para que o rico seja rico. O mundo sempre foi assim. E há de ser sempre assim. É Deus quem o quer...” Assim fala o latifundiário ao camponês. Usa o nome de Deus para assustar-te. Porque tu crês em Deus. Porém esse Deus do latifundiário não é teu Deus. Teu Deus é manso como um cordeiro. Se chama Jesus Cristo. Nasceu em um estábulo. Viveu entre os pobres. Se rodeou de pescadores, camponeses, operários e mendigos. Queria a li- 
berdade de todos eles. Dizia que a terra devia ser de quem trabalha. E o fruto era comum. São suas as seguintes palavras: “É mais fácil um camelo passar por um buraco de uma agulha, que um rico entrar no reino dos céus.” Porque afirmava essas coisas foi crucificado pelos latifundiários do seu tempo. Hoje seria fuzilado. Ou o internariam num asilo de loucos. Ou seria preso como comunista. Escuta bem o que te digo camponês. Se um padre ou pastor te fala em nome de um Deus que ameaça o povo com peste, guerra e fome, raios e trovões e o fogo do inferno, saiba que esse padre ou esse pastor são servos do latifúndio e não um ministro de Deus. ${ }^{29}$

A partir da análise dessa literatura, estudei como foi sendo produzida toda uma outra concepção de trabalhador, de religião, de patrão, de liberdade e de política entre os trabalhadores do campo.

Após esse longo percurso de estudos dos movimentos sociais no campo e na cidade, no território da política e suas várias representações e práticas, foi possível estabelecer diálogos e aproximações com diversificados aportes teóricos e metodológicos. A produção resultante desses diálogos e questionamentos esteve pautada pela análise intensa de documentos escritos e não escritos, e dessa forma pude operar deslocamentos analíticos que considero fundamentais nesta minha trajetória. E hoje isso passa a ser central na pesquisa As produções do medo: história e política no Nordeste (1955-1964), tema das minhas atuais investigações, que conta com o apoio do Conselho Nacional de Desenvolvimento Científico e Tecnológico do Brasil (CNPq).

Meu interesse maior, neste estudo, é analisar como foi sendo gestada, por intermédio de diversas redes, a representação do perigo que se afirmava como ameaça a toda a sociedade, e apareceria associada aos conceitos de medo e de violência. Investigo como a imprensa, a polícia, a Igreja Católica e muitas outras instituições construíram o lugar do perigo, do medo, da ameaça em relação ao que era objetivado como a ordem social e, ainda, como outras instituições incorporaram e ampliaram os efeitos dessa produção discursiva.

Meu plano de trabalho é analisar as estratégias discursivas e as práticas que instituíam a produção do medo, transformando-o em algo evidente, material e palpável. No âmbito dessa análise situa-se o estudo das redes que, de forma fragmentada, teciam esses discursos e concorriam para cimentar e solidificar a representação de ameaça iminente de destruição das instituições públicas e privadas, fundadas num sentimento de medo. Toda uma representação do medo foi sendo oferecida à população através da imprensa falada e escrita, dos púlpitos das igrejas, dos palanques políticos, das falas dos professores, dos livros e revistas. Ao leitor, ao ouvinte, ao aluno, às pessoas, coube acreditar, completar e am- 
pliar esse mundo que lhes era oferecido, em que eram convocados a posicionarse, a denunciar ou, talvez, inserir-se em outras redes discursivas e rechaçar o medo, ou ter dúvidas, ou não aceitar, ou não compreender. Isto é, torna-se necessário estar atento às múltiplas formas de apropriação do medo.

Mais de quatro décadas separam o tempo daquelas experiências sociais, políticas, culturais; outros discursos foram recriados, outros fragmentos lançados e outras rachaduras apresentadas, instituindo outros medos, outras ameaças, outros perigos, embora, talvez, o maior deles esteja ao lado daqueles que os apontam, os nomeiam, os objetivam.

\section{NOTAS}

2 MONTENEGRO, Antonio. Ligas camponesas e sindicatos rurais em tempo de revolução. In: FERREIRA, Jorge; NEVES, Lucília (Orgs.). O Brasil republicano: O tempo da experiência democrática - da democratização de 1945 ao golpe civil-militar de 1964. Rio de Janeiro: Civilização Brasileira, 2003. p. $24|-27|$.

${ }^{3}$ O termo 'DOPS' significa Departamento de Ordem Política e Social, criado para manter o controle do cidadão e vigiar as manifestações políticas na ditadura pós-64 instaurada no Brasil pelos militares. 0 DOPS perseguia, acima de tudo, as atividades intelectuais, sociais, políticas e partidárias do que considerava/imaginava ser de cunho comunista.

${ }^{4}$ Série de reportagens publicada no jornal Diário da Manhã do Rio de Janeiro, no período de 10 a 23 de setembro de 1959.

${ }^{5}$ Apud CASA Amarela: memórias, lutas, sonhos... Série I - Entrevistados: Antonio Vidal de Lima (Tôta), Arnaldo Rodrigues da Cruz, João Lopes da Silva (Bubu). Recife: Departamento de Memória de Casa Amarela (FEACA), 1988, p. 12-13.

${ }^{6}$ Apud CASA..., op. cit., p. $116-117$.

${ }^{7}$ Apud Ibid., p. 117-118.

8 MONTENEGRO, Antonio. Labirinto do medo: o comunismo (1950-1964). Clio, Recife, v. 22, p. $215-235,2004$

9 Diário de Pernambuco, Recife, 17 jan. 1962

10 MONTENEGRO, Antonio. As Ligas Camponesas às vésperas do golpe de 1964. Projeto História, São Paulo, v. 29, n. 2, p. 39|-416, 2004.

" MONTENEGRO, Antonio. Arquiteto da Memória: nas trilhas dos sertões de Crateús. In: GOMES, Ângela de Castro (Org.). Escrita de si, escrita da história. Rio de Janeiro: Editora FGV, 2004. p. 309. 334.

12 Entrevista realizada em fevereiro de 1998 com dom Xavier Gilles de Maupeou para o projeto de pesquisa Guerreiros do além-mar, com apoio do CNPq.

${ }^{13}$ Esse texto, após algumas adaptações, foi publicado em uma revista editada pelo Instituto Nacional de Antropología e História do México, com o título Historia de la Iglesia Católica en el nordeste de Brasil (1960-1990). Historias 59, Ciudad de México, 2004, p. 89- 108.

14 MONTENEGRO, Antonio. Rachar as palavras: uma história a contrapelo. Estudos Ibero-Americanos, Porto Alegre, v. 32, n. I, p. 37-62, jun. 2006.

${ }^{15}$ Apud CAPRA, Fritjof. O ponto de mutação: a ciência, a sociedade e a cultura emergente. São Paulo: Cultrix, 1991, p. 75. 
${ }^{16}$ Cf. Capra, loc. cit.

17 VEYNE, Paul. Como se escreve a história. São Paulo: Martins Fontes, 1980, p. 243.

${ }^{18}$ FOUCAULT, Michel. Verdade e poder. In: . Microfísica do poder. Rio de Janeiro: Graal, 1979,

p. 5 .

19 DELEUZE, Gilles. Conversações. 1972 - 1990. Rio de Janeiro: Ed. 34, 1992. p. I 51.

${ }^{20}$ CERTEAU, Michel de. A escrita da História. Rio de Janeiro: Forense Universitária, 2000, p. 51.

21 CERTEAU, op. cit., p. 52.

22 Nesse período, qualquer pessoa nomeada de comunista podia ser interrogada pela polícia ou mesmo presa.

${ }^{23}$ Cf. MONTENEGRO, Antonio. História oral e memória: a cultura popular revisitada. São Paulo: Contexto, 1992, p. 53.

24 Apud CASA Amarela: memórias, lutas, sonhos... Série I - Entrevistados: Antonio Vidal de Lima (Tôta), Arnaldo Rodrigues da Cruz, João Lopes da Silva (Bubu). Recife: Departamento de Memória de Casa Amarela (FEACA), 1988, p. 87.

25 Apud Ibid., p. 88.

26 Apud Ibid., p. 88.

27 MONTENEGRO, Antonio. A Frente do Recife chega ao poder ( 1955-1964). In: FERREIRA, Jorge; REIS, Daniel Aarão (Orgs.). As esquerdas no Brasil: nacionalismo e reformismo radical (1945-1964). Rio de Janeiro: Civilização Brasileira, 2005. p. 45।-488.

28 MONTENEGRO, Antonio. As Ligas Camponesas e os conflitos no campo. In: ARAÚJO, Rita de Cássia de; BARRETO, Túlio Velho (Orgs.). 1964: o golpe passado a limpo. Recife: Massangana, 2007. p. 93-|0|.

29 JULIÃO, Francisco. A CARTILHA DO CAMPONÊS. Recife. Setembro, 1960, p. 55-56. 